\title{
Dynamics of riverbank ephemeral plant communities in the Stryzhen' river estuary (Chernihiv, Ukraine)
}

\author{
Oleksandr Lukash*, Olena Kupchyk, Yuriy Karpenko, Alina Sliuta, Svitlana Kyrienko \\ Department of Ecology and Nature Conservation, T. Shevchenko National Pedagogical University of Chernihiv, \\ Hetman Polubotko Str., 53, 14013 Chernihiv, Ukraine, \\ *e-mail: lukash2011@ukr.net
}

\begin{abstract}
The authors investigated the dynamics of ephemeral plant communities in the Stryzhen' river estuary (N51 $29^{\prime} 17^{\prime \prime}$, E31 ${ }^{\circ} 18^{\prime} 57^{\prime \prime}$; Chernihiv, Ukraine; Eastern Polesia) after exposure to stress factors. The study of plant communities was carried out with generally accepted geobotanical methods. Samples of soil and water were analysed (in laboratory) using colorimetric methods and stripping voltammetry.

The research shows that edaphic and hydrological conditions in the riverside alluvial sediment near the Stryzhen' river estuary have changed under the influence of meteorological factors (mainly rainfalls). These changes have induced vegetation succession. In the monitored area, we observed a decrease in the concentration of nitrate, an increase in ammonia nitrogen content, the accumulation of sulphates, phosphates and salts of $\mathrm{Zn}^{2+}, \mathrm{Pb}^{2+}, \mathrm{Cu}^{2+}$, which came from rainfall and melt water. The accumulation of heavy metal salts did not reduce the formation of plant communities. The prognosis of further vegetation changes in the monitored alluvial area has been made. An increase in the area of communities on rich, low salified soils (order Agrostietalia stoloniferae Oberdorfer in Oberdorfer et al. 1967) is anticipated.

Locations of Crypsis schoenoides (L.) Lam. and Dichostylis micheliana (L.) Nees. were identified for the first time in the Chernihiv region. Diaspora of these plants arrived in the Stryzhen' river estuary through hydrochory along the northwest migratory route and the upper river that originates near the border of Ukraine and Belarus.
\end{abstract}

Key words: ephemeral plant communities, succession, Crypsis schoenoides (L.) Lam., Dichostylis micheliana (L.) Nees., the Stryzhen' river, Chernihiv region, Eastern Polissia.

\section{Introduction}

Pioneer ephemeral vegetation is one of the most dynamic components of the river floodplain. Research on the riverbank ephemeral plant communities was conducted in North America (Marks, 1983; Turner et al., 2005), Europe (Pietsch, 1973; Brullo \& Minissale, 1998; Popiela, 1999, 2005; Popiela et al., 2009) and Siberia (Taran, 1993, 1994, 1995, 2006, 2009). However, these studies were focused on floristic composition of communities. No attention was paid to the dynamics of ephemeral plant communities in Eastern Europe.

The Stryzhen' river (Chernihiv, Ukraine) is consistently exposed to human impact. The main sources of pollution in the Stryzhen' river are untreated storm (melt, rain) water and unauthorized discharges of municipal and industrial sewage from urban areas, ploughing and agricultural work in the floodplain, heavy pollution of shores and water by domestic waste and systematic violations of water legislation on riverside protection zones, especially in the lower reaches of the river. In the estuary of the Stryzhen' river, engineering works were carried out in 2013, as a result of which riverside vegetation was destroyed. It was therefore interesting from a scientific and practical perceptive to investigate the dynamics of the riverside ecosystem component after exposure to the stress factor. 


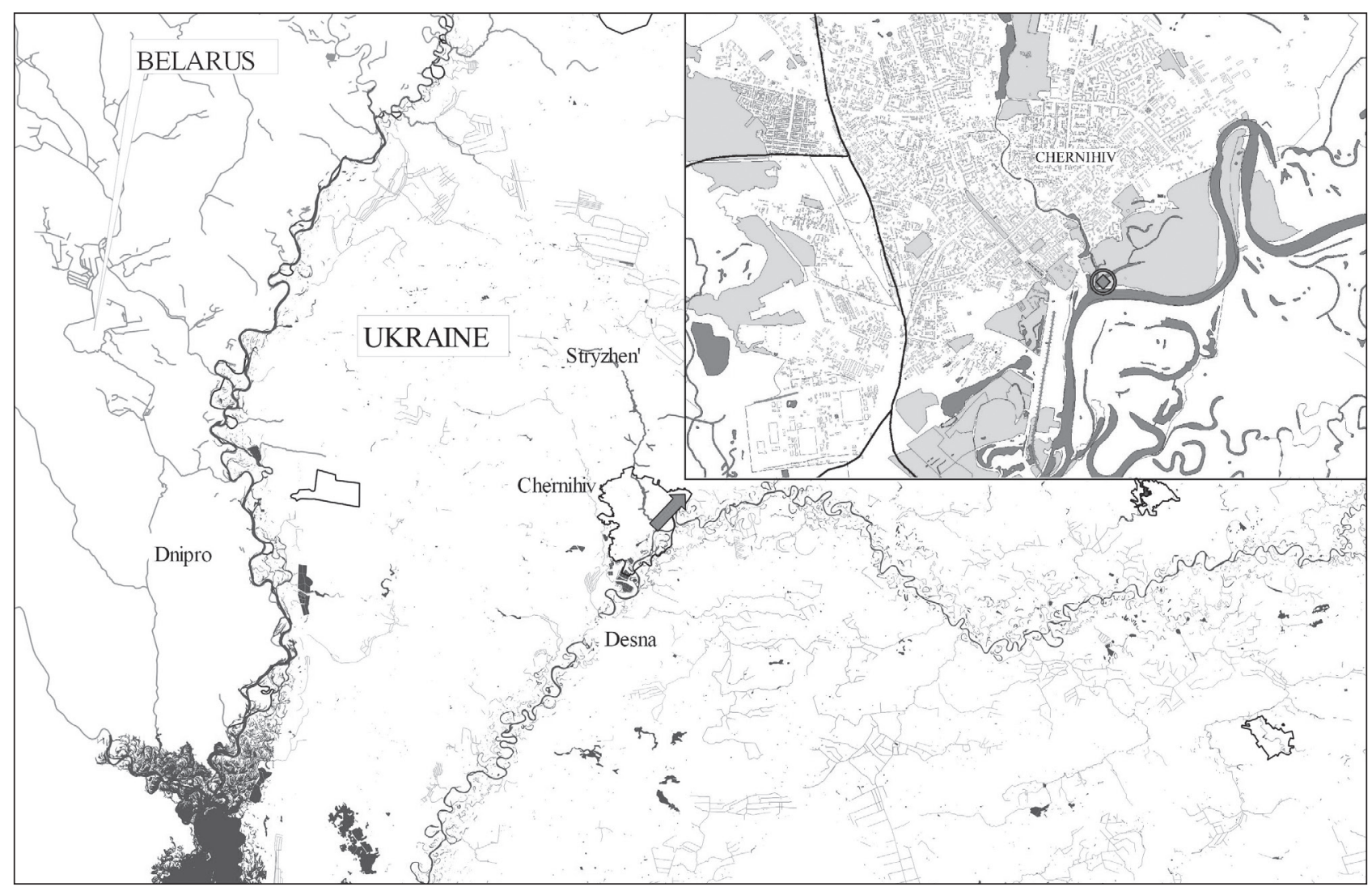

Figure 1. The study area: location of alluvial sediment (round sign)

\section{Study area}

The Stryzhen' river is situated in Eastern Polesia (Desna terrace plains and Chernihiv-Horodnia outwash sand plains). It belongs to the basin of the Desna river as a rightbank tributary of the first order (Fig. 1). Natural vegetation covers $42.7 \%$ of the total river basin area. The river flows through the territory of the Chernihiv region. The length of the river is $32.4 \mathrm{~km}$, the catchment area is $158 \mathrm{~km}^{2} ; 8.0 \%$ of the river basin is covered with woods, $0.28 \%$ - with swamps and $57.3 \%$ - with arable lands. The source of the river is located $2.5 \mathrm{~km}$ to the west of the village Veliky Osniaky, Ripky district, Chernihiv region, $150.00 \mathrm{~m}$ above sea level. The flow rate of the river is 14.0 million $\mathrm{m}^{3}$. The course of the river is poorly regulated. In total there are five ponds and reservoirs that regulate the local flow, and their total volume is 1.531 million $\mathrm{m}^{3}$. The river water belongs to the calcium bicarbonate class, its hardness is 4.2-4.9 mg Eq/1, its total mineralization is $290-320 \mathrm{mg} / 1$. The regime of the Stryzhen' river corresponds to the east European type. The river is fed mostly by snow and rain.

The Stryzhen' river basin is highly cultivated: 7 villages and the city of Chernihiv are located within the basin. The status of some environmental factors and direction of the processes occurring make the current overall ecological situation in the Stryzhen' river basin unsatisfactory.

\section{Material and methods}

The dynamics of the riverbank plant communities was studied in the Strizhen' estuary, between the forest natural boundary in Kordovka and the Val park (N51 ${ }^{\circ} 29^{\prime} 17^{\prime}$, E3 $\left.1^{\circ} 18^{\prime} 57^{\prime \prime}\right)$. The material for the paper was collected in 2014-2016. It includes geobotanical descriptions, herbarium materials, and the results of laboratory analyses.

Geobotanical research was carried out in September 2014-2016 over the area of $30 \mathrm{~m}^{2}(2 \mathrm{~m} \times 15 \mathrm{~m})$. The height of a plant community, the number of plant species, the total projective cover and the projective cover of each species were noted. Syntaxa were identified according to W. Matuszkiewicz (2001).

Soil sampling was carried out. A mixed sample was collected from the plot, which consisted of 5 samples collected by the envelope method (in the corners and the centre). Samples were collected at a depth of 0-20 cm horizontally in 5 replications. Fresh mass material was $1 \mathrm{~kg}$. The average sample was collected by quartering. Next, the soil 
was air dried at room temperature. The soil was purified from various components by sieving through a sieve with a mesh diameter of $0.5 \mathrm{~mm}$.

Samples of soil and water were subjected to laboratory analysis. Colorimetric measurements were carried out on a portable photocolorimeter with built-in analytical programs AQ4000. The content of heavy metals $\left(\mathrm{Zn}^{2+}, \mathrm{Cd}^{2+}\right.$, $\mathrm{Pb}^{2+}, \mathrm{Cu}^{2+}$ ) in the soil and water was determined by stripping voltammetry. The Voltammetric Lab Analyzer (NPP "Tomanalyt", Russia) was used. The calculation of metals' concentration was carried out using a special computer program TA-Lab (version 3.6.10).

\section{Results and discussion}

According to meteorological observations in 2014 compared to 2015 and 2016, the spring was very warm, the summer was moderately warm, the driest periods were spring and autumn, and the highest rainfall was recorded in summer (Figs 2, 3). The weather conditions and the waterlogged nitrificated substrate $\left(\mathrm{NO}_{3}{ }^{-}\right.$concentration was 6.182 $\mathrm{mg} / \mathrm{kg}$; see Table 1) were favourable for the formation of the association Chenopodietum glauco-rubri Lohm. 1950.

The height of the herbage was $95 \mathrm{~cm}$, the total projective cover was $60 \%$ (Table 2 , description 1 ). The following diagnostic species of the association Chenopodietum glauco-rubri Lohm. 1950 were identified: Chenopodium album L. and Blitum rubrum (L.) Rchb. with the projective cover of $20 \%$ and Blitum glaucum (L.) W.D.J. Koch $-10 \%$. In addition, typical species of the alliance Chenopodion fluviatile R. Tx. 1960 (Atriplex prostrata Boucher ex DC., Bidens frondosa L., Echinochloa crus-galli (L.) P. Beauv.), the order Bidentetalia tripartiti Br.-Bl. et R. Tx. 1943 and the class Bidentetea tripartiti R. Tx., Lohmeyer et Preising 1950 (Bidens tripartita L., Rorippa palustris (L.) Besser) occurred with the projective cover of up to $5 \%$. Single individuals of Xanthium albinum (Widder) $\mathrm{H}$. Scholz - a diagnostic species of the association Xanthio riparii-Chenopodietum Lohm. et Walther 1950 and Persicaria hydropiper (L.) Delarbre - a diagnostic species of the association Polygono-Bidentetum (Koch 1926) Poli et J. Tx. 1960 occurred. The latter association belongs to the alliance Bidention tripartiti Nordhagen 1940, which is represented by Bidens cernua L. and Catabrosa aquatica (L.) P. Beauv. (single plants occurred).

Scattered specimens of specific species from the class Stellarietea mediae R. Tx., Lohmeyer et Preising 1950 (Alsine media L., Galeopsis speciosa Mill.) and the order Polygono-Chenopodietalia (R. Tx. et Lohmeyer 1960) J. Tx. 1961 (Capsella bursa-pastoris (L.) Medik., Chenopodium album L., Polygonum aviculare L.) were found at the site. This reflects the ephemeral and ruderal type of the developed community.

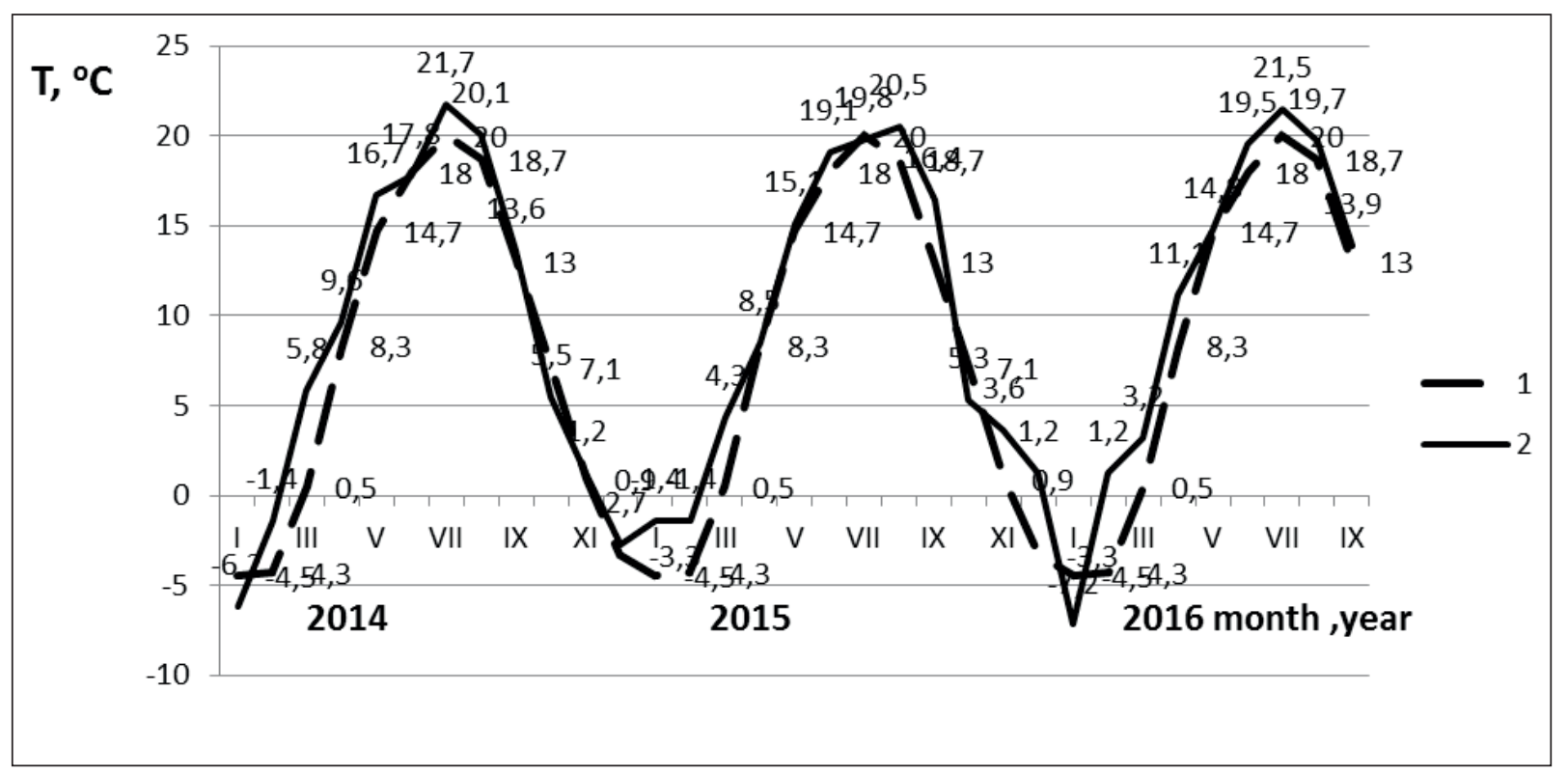

Figure 2. Dynamics of air temperature in the city of Chernihiv for the period from January 2014 to September 2016. Legend: 1 - average rate of temperature $\left({ }^{\circ} \mathrm{C}\right), 2$ - the actual average temperature $\left({ }^{\circ} \mathrm{C}\right)$ (the data of meteorological station "Chernihiv") 


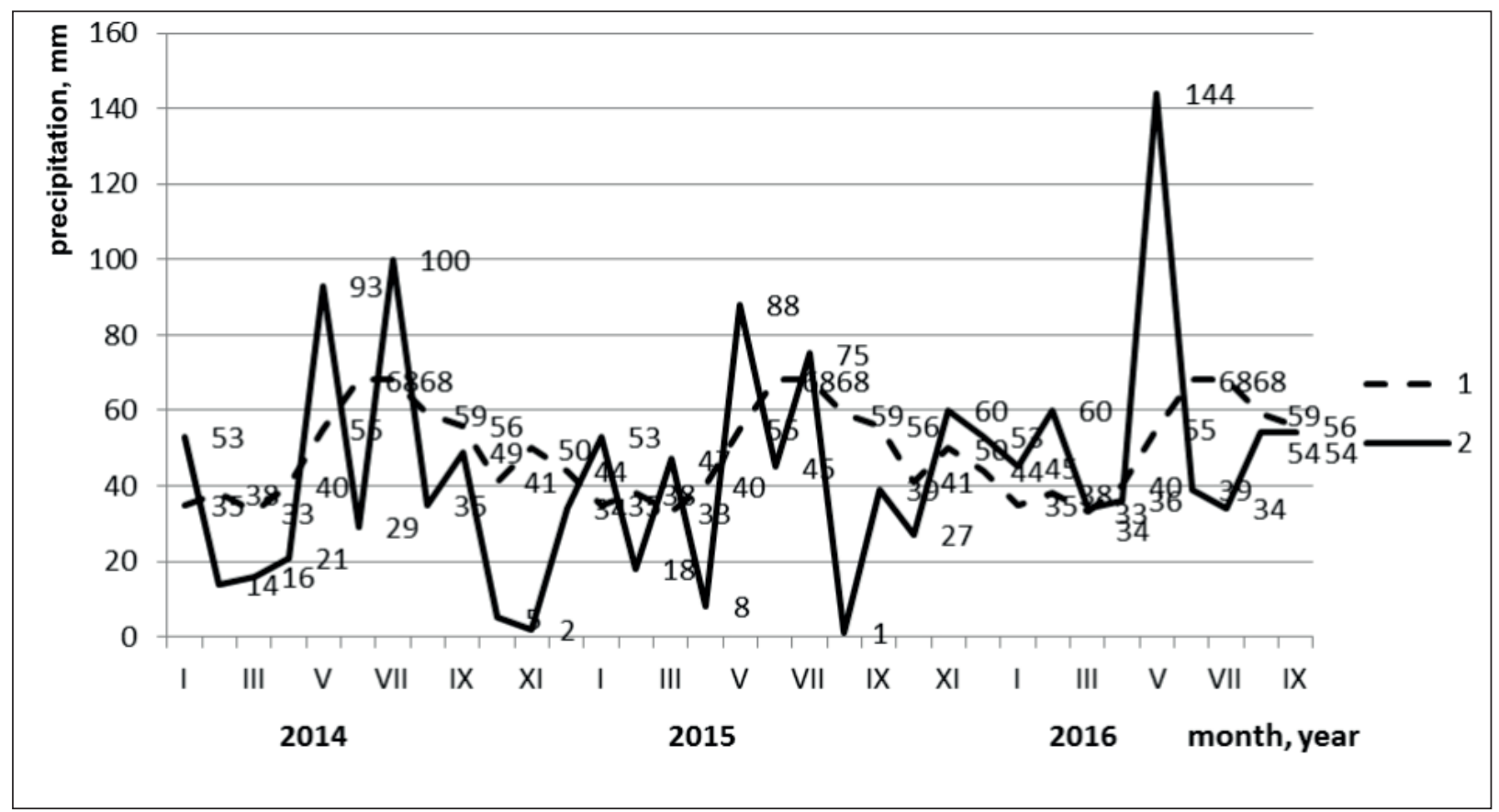

Figure 3. Dynamics of rainfalls in the city of Chernihiv for the period from January 2014 to September 2016. Legend: 1 - rate amount of precipitation for the month $(\mathrm{mm}), 2$ - the actual rainfall for the month $(\mathrm{mm})$ (the data of meteorological station "Chernihiv")

Table 1. Physical and chemical characteristics of substrates in monitored riverside areas of alluvial sediment near Stryzhen' river estuary

\begin{tabular}{|c|c|c|c|c|c|c|}
\hline The plot investigated & 1 & 1 & 1a & $1 b$ & $1 \mathrm{c}$ & $1 \mathrm{c}$ \\
\hline Year & 2014 & 2015 & 2016 & 2016 & 2016 & 2016 \\
\hline Substance & soil & soil & soil & soil & soil & water \\
\hline Color of solution & light & light & light & light & dark & greenish-yellow \\
\hline $\mathrm{pH}$ & 7 & 7 & 7 & 7 & 6 & 6 \\
\hline Ions & \multicolumn{6}{|c|}{ concentration, $\mathrm{mg} / \mathrm{kg}$} \\
\hline $\mathrm{SO}_{4}^{2-}$ & 5.697 & 5.714 & 5.749 & 15.360 & 164.805 & 113.900 \\
\hline $\mathrm{NO}_{3}^{-}$ & 6.182 & 3.123 & 1.325 & 3.088 & 1.146 & 0.598 \\
\hline $\mathrm{PO}_{4}^{3-}$ & 6.124 & 6.532 & 6.721 & 8.185 & 8.363 & 15.81 \\
\hline $\mathrm{NH}_{4}^{+}$ & 0.881 & 0.948 & 1.090 & 1.004 & 1.125 & 2.615 \\
\hline $\mathrm{Mn}^{2+}$ & 0.364 & 0.343 & 0.259 & 0.376 & 0.436 & 0.465 \\
\hline $\mathrm{Fe}^{(2+, 3+)}$ & 0.164 & 0.142 & 0.139 & 0.118 & 0.131 & 0.098 \\
\hline $\mathrm{Zn}^{2+}$ & 0.0005 & 0.0017 & 0.0038 & 0.0124 & 0.0650 & 0.3192 \\
\hline $\mathrm{Cd}^{2+}$ & 0 & 0 & 0 & 0 & 0 & 0 \\
\hline $\mathrm{Pb}^{2+}$ & 0.0017 & 0.0021 & 0.0051 & 0.0062 & 0.0074 & 0.0078 \\
\hline $\mathrm{Cu}^{2+}$ & 0.0023 & 0.0043 & 0.0075 & 0.0091 & 0.0271 & 0.0472 \\
\hline
\end{tabular}


Table 2. The floristic structure of plant communities in monitored riverside areas of alluvial sediment near Stryzhen' river estuary

\begin{tabular}{|c|c|c|c|c|c|}
\hline Number of relevé & 1 & 2 & 3 & 4 & 5 \\
\hline Plot & 1 & 1 & $1 \mathrm{a}$ & $1 \mathrm{~b}$ & $1 \mathrm{c}$ \\
\hline Date of description & 19.09.2014 & 12.09 .2015 & 28.09 .2016 & 28.09 .2016 & 28.09 .2016 \\
\hline Sublayers, first height $(\mathrm{cm})$ & 95 & 60 & 40 & 15 & 70 \\
\hline Sublayers, second height $(\mathrm{cm})$ & - & 5 & 5 & - & - \\
\hline Vegatation cover $(\%)$ & 60 & 70 & 50 & 40 & 40 \\
\hline Area $\left(\mathrm{m}^{2}\right)$ & 25 & 30 & 13 & 9 & 5 \\
\hline \multicolumn{6}{|c|}{ Ch. Ass. Dichostylido-Helochloetum alopecuroidis } \\
\hline Dichostylis micheliana & . & 3 & . & + & . \\
\hline Schoenoplectus supinus & . & + & . & . & . \\
\hline \multicolumn{6}{|c|}{ Ch. All. Heleochloo-Cyperion micheliani } \\
\hline Crypsis schoenoides & . & 3 & . & + & . \\
\hline \multicolumn{6}{|l|}{ Ch. Ass. Eleocharetum ovatae } \\
\hline Elatine hydropiper & . & + & . & . & . \\
\hline Elatine triandra & . & + & . & . & . \\
\hline Eleocharis ovata & . & 2 & . & + & . \\
\hline \multicolumn{6}{|c|}{ Ch. All. Elatini-Eleocharition ovatae } \\
\hline Eleocharis acicularis & . & + & . & . & . \\
\hline Cyperus fuscus & . & 2 & . & . & . \\
\hline \multicolumn{6}{|l|}{ Ch. O. Cyperetalia fusci } \\
\hline Gnaphalium uliginosum & 2 & 1 & . & 2 & . \\
\hline Potentilla supina & + & + & . & . & . \\
\hline \multicolumn{6}{|l|}{ Ch. Cl. Isoëto-Nanojuncetea } \\
\hline Centaurium pulchellum & + & + & . & . & . \\
\hline Juncus bufonius & + & + & 1 & + & . \\
\hline Juncus tenageia & + & + & + & . & . \\
\hline Plantago intermedia & . & + & . & . & . \\
\hline Potentilla supine & . & + & . & . & . \\
\hline \multicolumn{6}{|l|}{ Ch. Ass. Polygono-Bidentetum } \\
\hline Persicaria hydropiper & + & + & . & . & . \\
\hline \multicolumn{6}{|l|}{ Ch. All. Bidention tripartiti } \\
\hline Bidens cernua & + & . & + & + & + \\
\hline Ranunculus sceleratus & . & 2 & . & . & . \\
\hline Catabrosa aquatica & + & . & . & . & . \\
\hline \multicolumn{6}{|c|}{ Ch. Ass. Xanthio riparii-Chenopodietum } \\
\hline Xanthium albinum & + & 2 & + & + & . \\
\hline \multicolumn{6}{|c|}{ Ch. Ass. Chenopodietum glauco-rubri } \\
\hline Chenopodium album & 3 & . & . & . & . \\
\hline Blitum rubrum & 3 & 2 & + & + & . \\
\hline Blitum glaucum & 2 & . & . & . & . \\
\hline \multicolumn{6}{|l|}{ Ch. All. Chenopodion fluviatile } \\
\hline Atriplex prostrata & 1 & . & . & . & . \\
\hline Bidens frondosa & 1 & . & . & . & . \\
\hline Echinochloa crusgalli & 1 & . & + & + & . \\
\hline \multicolumn{6}{|l|}{ Ch. O. Bidentalia tripartiti } \\
\hline \multicolumn{6}{|l|}{ Ch. Cl. Bidenttea tripartita } \\
\hline Bidens tripartita & 1 & 2 & + & . & . \\
\hline Rorippa palustris & + & . & + & . & . \\
\hline \multicolumn{6}{|l|}{ Ch. O. Polygono-Chenopodietalia } \\
\hline Capsella bursa-pastoris & + & . & . & . & . \\
\hline Chenopodium album & + & . & . & . & . \\
\hline Polygonum aviculare & + & . & . & . & . \\
\hline
\end{tabular}




\begin{tabular}{|c|c|c|c|c|c|}
\hline Number of relevé & 1 & 2 & 3 & 4 & 5 \\
\hline \multicolumn{6}{|l|}{ Ch. Cl. Stellarietea mediae } \\
\hline Alsine media & + & . & + & . & . \\
\hline Galeopsis speciosa & . & . & + & + & . \\
\hline \multicolumn{6}{|c|}{ Ch. Ass. Ranunculo-Alopecuretum geniculati } \\
\hline Inula britannica & . & + & 3 & . & . \\
\hline Alopecurus geniculatus & . & . & 2 & . & . \\
\hline Potentilla reptans & . & . & 3 & . & . \\
\hline Rorippa sylvestris & . & . & 1 & . & . \\
\hline Rumex crispus & . & . & + & . & . \\
\hline \multicolumn{6}{|l|}{ Ch. All. Agropyro-Rumicion crispi } \\
\hline \multicolumn{6}{|l|}{ Ch. O. Agrostietalia stoloniferae } \\
\hline Elytrigia repens & . & . & + & + & . \\
\hline Blysmus compressus & . & . & + & + & . \\
\hline Mentha longifolia & . & . & + & . & + \\
\hline Juncus compressus & . & . & + & . & . \\
\hline Juncus inflexus & . & . & + & . & . \\
\hline Potentilla anserine & . & . & + & + & . \\
\hline Ranunculus repens & . & . & + & + & + \\
\hline \multicolumn{6}{|l|}{ Ch. Ass. Prunello-Plantaginetum } \\
\hline Plantago major & . & . & + & 3 & . \\
\hline Роа аппиа & . & . & . & 2 & . \\
\hline \multicolumn{6}{|l|}{ Ch. All. Polygonion avicularis } \\
\hline \multicolumn{6}{|l|}{ Ch. O. Plantaginetalia majoris } \\
\hline Geum urbanum & . & . & . & + & . \\
\hline Juncus tenuis & . & . & . & + & . \\
\hline Lolium perene & . & . & . & + & . \\
\hline Prunella vulgaris & . & . & . & + & . \\
\hline Lepidotheca suaveolens & . & . & . & + & . \\
\hline \multicolumn{6}{|l|}{ Ch. Cl. Molinio-Arrhenatheretea } \\
\hline Plantago lanceolata & . & . & + & + & . \\
\hline Ranunculus acris & . & . & + & + & . \\
\hline Trifolium pretense & . & . & + & + & . \\
\hline Ch. Ass. Typhetum angustifoliae & & & . & . & . \\
\hline Typha angustifolia & . & . & . & . & + \\
\hline \multicolumn{6}{|c|}{ Ch. Ass. Sagittario-Sparganietum emersi } \\
\hline Sagittaria sagittifolia & . & . & . & . & 4 \\
\hline Sparganium emersum & . & . & . & . & 1 \\
\hline \multicolumn{6}{|l|}{ Ch. All. Phragmition } \\
\hline Butomus umbellatus & . & . & . & . & 1 \\
\hline Nuphar lutea var. terrestris & . & . & . & . & + \\
\hline \multicolumn{6}{|l|}{ Ch. O. Pragmitetalia } \\
\hline \multicolumn{6}{|l|}{ Ch. Cl. Phragmitetea } \\
\hline Carex acuta & . & . & . & . & 1 \\
\hline Phragmites australis & . & . & . & . & 1 \\
\hline Alisma plantago-aquatica & . & . & . & . & + \\
\hline \multicolumn{6}{|l|}{ Other species } \\
\hline Persicaria maculosa & . & . & + & . & . \\
\hline Riccia fluitans & . & + & . & . & . \\
\hline Rumex ucranicus & . & 2 & . & . & . \\
\hline Salix viminalis & . & . & + & . & . \\
\hline
\end{tabular}

Note. Cover abundance scale: +- less than 1\%, 1-1-5\%, 2-6-12\%, 3-13-25\%, 4-26-50\%; authors of relevés: O. Lukash., Yu. Karpenko 
In 2014, the content of ions (excluding $\mathrm{NO}_{3}{ }^{-}$and $\mathrm{Mn}^{2+}$ ) in soil samples had the lowest value compared to the other years of the observations (Table 1).

Thus, the main identified factors favourable (directly and indirectly) for the ruderal ephemeral community Chenopodietum glauco-rubri Lohm. 1950 were high nitrate levels in the soil and the amount of summer rainfall.

In Chernihiv, the period from autumn 2014 to summer 2015 was characterized by a deficit of rainfalls (Fig. 2), which contributed to the drawdown of groundwater levels and reduced water levels in the Stryzhen' bed. This led to the retreat of the river bank by $30 \mathrm{~cm}$ and an increase in the area of riverine sands. It was found that in 2015, the ephemeral communities were formed on slightly damp sand, the surface of which was covered with a thin $(1 \mathrm{~cm})$ layer of silt. The communities grew over an area of $2 \mathrm{~m}^{\prime} 15$ $\mathrm{m}$ between ruderal communities of the alliance Bidention tripartiti Nordhagen 1940, formed by Bidens tripartite L., $B$. cernua L. and B. frondosa L. and flooded areas with the association Butomo-Sagittarietum sagittifoliae Losev in Losev et V. Golub 1988, Sparganietum erecti Roll 1938 and Potameto-Nupharetum Müller et Görs 1960.

The soil at the site monitored in 2015 compared to the previous year contained almost two times smaller (but significant) amount of nitrates and a slightly lower content of $\mathrm{Mn}^{2+}$ (Table 1). For other ions, a slightly increased concentration was observed.

The projective cover of the described communities was $70 \%$ (Table 2). It included single typical species of the class Isoëto-Nanojuncetea Br.-Bl. et R. Tx. 1943: Centaurium pulchellum (Sw.) Druce, Juncus bufonius L., Juncus tenageia Ehrh. ex L.f., Plantago intermedia Gilib. Diagnostic species of the order Cyperetalia fusci Pietsch 1963 (Gnaphalium uliginosum L. - 5\% and Potentilla supina L. - single plants) were found. Typical species of the alliance Elatini-Eleocharition ovatae Pietsch 1965 were represented by scattered individuals of Eleocharis acicularis (L.) Roem. et Schult. and Cyperus fuscus L., the projective cover of which was up to $8 \%$. Riccia cavernosa Hoffm. - a liverwort species typical for such communities in Central Europe - was missing. Instead, dichotomously branched thalli of Riccia fluitans L. were found on the moist soil. Diagnostic species of the association Eleocharitetum ovatae Hayek 1923 were represented by rare species of European plants - Elatine hydropiper L. and E. triandra Schkuhr, and Eleocharis ovata (L.) Roem. et Schult. (7\%), but Carex bohemica Schreb. was absent. The described community was co-dominated by Crypsis schoenoides (L.) Lam. - a diagnostic species of the alliance Heleochloo-Cyperion micheliani (Br.-B1. 1952) Pietsch 1961 and Dichostylis micheliana (L.) Nees. (with projective cover of $20 \%$ and $25 \%$, respectively). According to the literature data (Pietsch, 1991), Crypsis schoenoides (L.) Lam. and Dichostylis micheliana (L.) Nees need 8-15 days for seed germination. According to the data from the hydrological post "The Stryzhen' river", the age of the bank was 94 days, so the age of the community was 79-86 days. Dichostylis micheliana (L.) Nees is a diagnostic species of the association Dichostylido-Helochloetum alopecuroidis (Timar 1950) Pietsch 1973, described in Hungary (Pietsch, 1973) and Russia (Taran, 2006). However, Lythrum hissopifolia L., Lythrum tribracteatum Salzm. ex Spreng., Crypsis alopecuroides (Pill. et Mitt.) Host ex Roem. and other species typical for the association were not found in the riverbank ephemeral plant communities in the Stryzhen' river estuary. The characteristic feature of the described community is the presence of Rumex ucranicus Fisch. ex Spreng. (8\%) and Blitum rubrum (L.) Rchb. f. humile (6\%). Few individuals of Schoenoplectus supinus (L.) Palla (a typical species of the association Dichostylido-Helochloetum alopecuroidis (Timar 1950) Pietsch 1973, described in Hungary) were found. In this community, other species of plant communities adjacent to that area were well represented. In particular, diagnostic species of different associations from the alliance Bidention tripartiti Nordh. 1940 - Bidens tripartita L., B. cernua L., Persicaria hydropiper (L.) Delarbre, Xanthium albinum (Widder) H. Scholz, Ranunculus sceleratus L. - have projective cover of 5-10\%. Other species occurred as single specimens: diagnostic species of the alliances Agropyro-Rumicion crispi Nordhagen 1940 em. R. Tx. 1950 (Rorippa sylvestris (L.) Besser, Inula britannica L.), Polygonion avicularis Br.-B1. 1931, 1933 ex Aich (Polygonum aviculare L., Poa annua L., Juncus tenuis Willd.) and Phragmition W. Koch 1926 (Butomus umbellatus L., Sagittaria sagittifolia L.).

Thus, the phytocoenosis developed in 2015 can be diagnosed as transitional between Eleocharetum ovatae Hayek 1923 and Dichostylido-Helochloetum alopecuroidis (Timar 1950) Pietsch 1973. Its formation was influenced by weather conditions, which indirectly exposed the habitat, and favourable edaphic factors (moderate salinity and high nitrate content).

It should be noted that Crypsis schoenoides (L.) Lam. and Dichostylis micheliana (L.) Nees were not previously recorded in the area of Chernihiv. According to the Herbarium of V.F. Kuprevych Institute of Experimental Botany NASB $(M W)$, the nearest location of these species are in the border zone between Ukraine and Belarus, to the south and southwest of the Gomel region (Belarus). Probably the diaspora of these plants arrived in the Stryzhen' river estuary through hydrochory along the northwest migratory route, through the upper river that originates near the border of Ukraine and Belarus.

There was a significant amount of rainfall between the winter of 2015 and the summer of 2016 (Fig. 2). In September 2016, the runoff of rainwater and melting snow divided the ephemeral riverbank area into three fragmented zones. Communities of slightly saline, periodically flooded 
soils developed over a plain moderately moist area, i.e. Ranunculo-Alopecuretum geniculati R. Tx. 1937 (Table 2, section 1a; $37 \%$ of the total area). Ruderal communities of Prunello-Plantaginetum Faliński 1963 (Table 2, section $1 \mathrm{~b} ; 33 \%$ of the total area) with juvenile individuals of $S a$ lix viminalis $\mathrm{L}$. were found on the hill with a nitrificated (Table 1) sandy, dry and hardened substrate. In depressions with silty and sandy bottom sediments and small amounts of water, the aquatic-terrestrial community Sagittario-Sparganietum emersi R. Tx. 1953 (Table 2, plot 1c; $30 \%$ of the total area) was found.

Diagnostic species of the association Ranunculo-Alopecuretum geniculati R. Tx. 1937 are well represented in the community: Inula britannica L. (20\%), Alopecurus geniculatus L. (10\%), Potentilla reptans L. (23\%), Rorippa sylvestris (L.) Besser (1\%), Rumex crispus L. (single plants). Diagnostic species of the alliance Agropyro-Rumicion crispi Nordhagen 1940 em. R. Tx. 1950 and the order Agrostietalia stoloniferae Oberdorfer in Oberdorfer et al. 1967 were represented by single individuals of Elytrigia repens (L.) Nevski, Blysmus compressus (L.) Panz. ex Link, Mentha longifolia L., Juncus compressus Jacq., Juncus inflexus L., Potentilla anserina L. and Ranunculus repens L. The characteristic species of the class were represented by Juncus bufonius L. (7\%) and Juncus tenageia Ehrh. (single plants). Also single annual weeds occurred: Echinochloa crusgalli (L.) P. Beauv., Bidens cernua L., Bidens tripartite L., Xanthium albinum Widder) H. Scholz, Alsine media L., Galeopsis speciosa Mill., Persicaria maculosa Gray, Blitum rubrum (L.) Rchb.

The comparison of the results of chemical analysis of the soil from the plot (2016) and from the whole monitored area (2015) shows a decrease in the concentration of nitrate ions $(58 \%), \mathrm{Mn}^{2+}(25 \%)$, an increase in $\mathrm{NH}_{4}^{+}(14 \%)$ and nearly two times higher concentration of heavy metal ions $\left(\mathrm{Zn}^{2+}, \mathrm{Pb}^{2+}, \mathrm{Cu}^{2+}\right)$ (Table 1).

The community Prunello-Plantaginetum Faliński 1963, consisting of two sublayers, was diagnosed by the presence of Plantago major L. (21\%) and Poa annua L. (10\%). There were few individual species specific to the alliance Polygonion avicularis Br.-Bl. 1931 ex Aichinger 1933, the order Plantaginetalia majoris R. Tx. 1937 (Geum urbanum L., Juncus tenuis Willd., Lolium perene L., Prunella vulgaris L., Lepidotheca suaveolens (Pursh) Nutt.) and the class Molinio-Arrhenatheretea R. Tx. 1937 (Plantago lanceolata L., Ranunculus acris L.). The remains of the ephemeral coenosis were represented by Crypsis schoenoides (L.) Lam. and Dichostylis micheliana (L.) Nees (3-4 $\mathrm{cm}$ height), as well as small spots of Gnaphalium uliginosum L. and single individuals of Eleocharis ovata (Roth) Roem \& Schult. and Juncus bufonius L. Furthermore, we found a few specimens of Echinochloa crus-galli (L.) P. Beauv., Bidens cernua L., Xanthium albinum (Widder) H. Scholz, Alsine media L., Galeopsis speciosa Mill., Persi- caria maculosa Gray, Blitum rubrum (L.) Rchb. Rhizomatous species (Elytrigia repens (L.) Nevski, Blysmus compressus (L.) Panz. ex Link) and ground creeping species (Potentilla anserine L., Ranunculus repens L.) encroached the from neighbouring phytocenoses.

The species composition of the community is connected with relevant edaphic conditions, particularly a high content of anions in the soil (Table 1) - nitrates (3.088 $\mathrm{mg} / \mathrm{kg})$, sulphates $(15.360 \mathrm{mg} / \mathrm{kg})$ and phosphates $(8.185$ $\mathrm{mg} / \mathrm{kg})$.

Diagnostic species of the association Sagittario-Sparganietum emersi R. Tx. 1953 are Sagittaria sagittifolia L. and Sparganium emersum Rehmann - aquatic-terrestrial species of a broad ecological amplitude. The projective cover in area 1c (Table 2) was 35\% and 5\% respectively. In addition to the diagnostic species of the association, characteristic species of the alliance Phragmition W. Koch 1926 (Butomus umbellatus L., the terrestrial form of Nuphar lutea (L.) Smith), the order Pragmitetalia W. Koch 1926 and the class Phragmitetea R. Tx. et Prsg 1942 (Phragmites australis (Cav.) Trin. ex Steud., Alisma plantago-aquatica L., Carex acuta L.) occurred.

The habitat of the community Sagittario-Sparganietum emersi R. Tx. 1953 can be defined as a marsh ecophase. The silty and sandy substrate of the habitat has an excessive content of sulphates $(164.805 \mathrm{mg} / \mathrm{kg})$, high concentrations of phosphates $(8.185 \mathrm{mg} / \mathrm{kg})$, reduced concentration of nitrates $(1.146 \mathrm{mg} / \mathrm{kg})$, increased concentration of ammonia nitrogen $(1.25 \mathrm{mg} / \mathrm{kg})$ compared with figures for neighbouring areas and monitoring sites (in 2014-2015). Compared to the solid substrate in water, the content of $\mathrm{SO}_{4}{ }^{2-}$ was slightly lower $(113.9 \mathrm{mg} / \mathrm{kg})$, the concentration of $\mathrm{PO}_{4}^{3-}$ almost two times lower $(15.81 \mathrm{mg} / \mathrm{kg}), \mathrm{NO}_{3}{ }^{-}-$ more than two times lower $\left(0.598 \mathrm{mg} / \mathrm{kg}\right.$ and $\mathrm{NH}_{4}^{+}$two and half times higher $(2.615 \mathrm{mg} / \mathrm{kg})$. Nitrates as products of biochemical oxidation of ammonia salt compounds are unstable and available only at relatively recent contamination. The quantity of ammonium sharply increases with recent water or soil contamination. The increase of nitrates in the soil and reservoirs indicates the intensity of nitrification.

As appears from Table 1, water and soil samples from area 1c contain significant amounts of heavy metals (except $\mathrm{Cd}^{2+}$, which was not found in any of the samples) compared to the other soil samples. In water of the Stryzhen', concentration of $\mathrm{Zn}^{2+}, \mathrm{Pb}^{2+}, \mathrm{Cu}^{2+}$ salts amounted to $0.0014,0.0029$ and $0.0031 \mathrm{mg} / \mathrm{kg}$. Probably the heavy metal salts were brought by rain and melt water to the newly alluvial sediment from the road adjacent to the river. The content of iron ions in all soil and water samples collected from monitoring sites in the period of 2014-2016 corresponds to the Chernihiv region.

The water level and chemical indicators of the community Sagittario-Sparganietum emersi R. Tx. 1953 habitat 
are not optimal. Communities of this association are not resistant to salinity and are best developed in the riverbank ecophase. Their vitality and productivity is reduced under conditions of lower moisture and lower water content and increasing anthropogenic eutrophication of water bodies (Dubyna, 2006). The high content of heavy metals does not reduce the expansion of plant communities.

\section{Conclusions}

The research shows that edaphic and hydrological conditions in the riverside alluvial sediment near the Stryzhen' estuary have changed under the influence of meteorological factors (mainly rainfall). The ecological and coenotic sequence of succession is as follows: nitrophilous community Chenopodietum glauco-rubri Lohm. $1950 \rightarrow$ community of therophytes, transitional from Eleocharetum ovatae Hayek 1923 to Dichostylido-Helochloetum alopecuroidis (Timar 1950) Pietsch $1973 \rightarrow$ halophilous community Ranunculo-Alopecuretum geniculati R. Tx. $1937+$ ruderal community Prunello-Plantaginetum Faliński 1963 + aquatic-terrestrial community Sagittario-Sparganietum emersi R. Tx. 1953.

Based on the determined course of succession it can be predicted that further changes in the vegetation will occur at the monitored alluvial site leading to the increasing area of communities Agrostietalia stoloniferae Oberdorfer in Oberdorfer et al. 1967 on rich, slightly saline soils.

Locations of Crypsis schoenoides (L.) Lam. and Dichostylis micheliana (L.) Nees were found for the first time in the Chernigov region. Diaspora of these plants arrived in the Stryzhen' river estuary through hydrochory along the northwest migratory route and the upper river that originates near the border of Ukraine and Belarus.

\section{References}

Brullo S. \& Minissale P., 1998, Considerazioni sintaksonomiche sulla classe Isoëto-Nanojuncetea, Itinera Geobotanica 11: 263-290.

Dubyna D.V., 2006, Higher aquatic vegetation, Yu. R. Shelyag-Sosonko (ed.), Kyiv: 265-267.

Marks P., 1983, On the origin of the field plants of the northeastern United States, The American Naturalist 122: $210-228$.

Matuszkiewicz W., 2001, Przewodnik do oznaczania zbiorowisk roślinnych Polski, [Guide for determination of Polish plant communities] Wydawnictwo Naukowe PWN, Warszawa.

Pietsch W., 1973, Zur Soziologie und Ökologie der Zwergbinsen-Gesellschaften Ungarns (Klasse Isoëto-Nano- juncetea Br.-B1. et R. Tx. 1943), Acta Botanica Academiae Hungaricae 19(1-4): 269-288.

Pietsch W., 1991. Investigations in vegetation dynamic of dwarf rush vegetation on dewatered pond floors in Central Europe, 34th IAVS Symposium on "Mechanics in Vegetation Dynamics", 26-30 August 1991, Eger, Hungary: 46.

Popiela A., 1999, Communitis and species of Isoëto-Nanojuncetea in Poland - syntaxonomic classification, distribution and current state of research, Mitt. bad. Landesver. Naturkunde u. Naurschutz N.F. 17 (2): 369380.

Popiela A., 2005, Isoëto-Nanojuncetea species and plant communities occurring on their eastern distribution range (Poland), Phytocenologia 35(2-3): 283-303.

Popiela A., Prajs B. \& Lysko A., 2009, New data on the distribution of dwarf ephemeral wetland vascular plant species and communities in western and north-western Poland, Biodiv. Res. Conserv. 15: 41-46.

Taran G.S., 1993, On syntaxonomy of Black Irtysh floodplain ephemerous vegetation, Siberian Journal of Biology 5: 79-84.

Taran G.S., 1994, Floodplain ephemeretum of Middle Oba new class for Siberia, Isoëto-Nanojuncetea Br.-Bl. et Tx. 1943 on the northern border of expansion, Siberian Journal of Ecology 1: 578-582.

Taran G.S., 1995, A little-known vegetation class of the former USSR-flood plain Ephemeretum, Siberian Journal of Ecology 2: 372-380.

Taran G.S., 2006, Association Dichostylidi-Helochloetum alopecuroidis (Timar 1950) Pietsch 1973 (Isoëto-Nanojuncetea) in the Volga River Delta, Vegetation of Russia 9: 69-75.

Taran G.S., 2009, Bottomland ephemeretum of Ob and Irtysh revers near Khanty-Mansiysk city, Vistnyk of Orenburg State University 2: 108-110.

Turner K., Lefler B. \& Freedman B., 2005, Plant communities of selected urbanized areas of Halifax, Nova Scotia, Canada, Landscape and Urban Planning 71: 191-206. 